\title{
Water Quality of the Middle and Lower Course of the Ibar River in two testing season
}

\author{
Saša Obradovićc ${ }^{1}$ \\ ${ }^{1}$ Faculty of Agriculture, Kosančićeva 4, Kruševac, Serbia
}

\section{Keywords:}

Water quality, Hydrogeographic characteristic, Ibar River.

\section{Introduction}

Surface waters are complex solutions consisting of several groups of different compounds, the most important of which are dissolved gases, biogenic elements, organic and mineral substances, which define its quality and on whose numerical values depends the classification of water in an area. Water quality is not over time and geographically stable, as it depends on natural and anthropogenic factors that can cause changes in water quality currently, seasonally or over a multi-year period (Dodds, 2002; Dalmacija et al., 2004).

Rivers in Serbia have a significant role in supplying the population with water, irrigating agricultural land, developing tourism, maintaining sports activities and recreation.
However, most of the rivers are the direct recipients of polluted water generated by human activity. According to the spatial plan draft of the Republic of Serbia from 2021 to 2035, about 409 million $\mathrm{m}^{3}$ of municipal wastewater in Serbia is discharged into surface waters through sewage systems annually, $87.9 \%$ of it not being treated. Due to the anthropogenic impact, harmful substances (heavy metals, pesticides, fecal microorganisms, etc.) can reach into the surface waters, which in a concentration higher than the MPC negatively affect the physical and chemical quality of water, aquatic organisms and indirectly human health. Surface water pollution is any qualitative and quantitative deviation from normal, physically natural, chemical or biological composition and properties, which has undesirable consequences for the ecosystem, economy and human health. Natural pollution 
occurs occasionally, and the main sources of anthropogenic pollution are industrial, mining and municipal wastewater and water from agricultural land (Simić et al., 2009).

Wastewater with a high concentration of pollutants causes a disruption of the natural balance in surface waters in the form of eutrophication and the appearance of toxic substances in water (pesticides, heavy metals). Therefore, wastewater poses a great danger to the flora and fauna of surface waters and normal water chemistry and can have a negative impact on human health. (Dalmacija et al., 2008; Pešić et al., 2017).

The aim of the study was to examine the physico-chemical and microbiological quality of the Ibar River in the period of high (May) and low waters (September) during 2019, as well as the anthropogenic impact on the pollution of the Ibar River. For each sampling location, 25 surface water quality parameters were analyzed. The study included three profiles of the Ibar River, located in the geographical area from the settlement of Rudnica, near the administrative border with Kosovo and Metohija, to the settlement of Baljevac, which is about $17 \mathrm{~km}$ from the town of Raška.

\section{Study area}

\subsection{Basic hydro geographic characteristics of the lbar River}

The Ibar River is the largest and most important tributary of the West Morava, which springs from six springs below the mountain Hajla (1360 m above sea level) in Montenegro, and flows into the West Morava near the town of Kraljevo. The Ibar belongs to the Black Sea basin, whose area is the largest of all other river basins in Serbia and amounts to $81,261 \mathrm{~km}^{2}$ or $92 \%$ of Serbia's water territory. The total length of the Ibar is $276 \mathrm{~km}$ with an area of $8059 \mathrm{~km}^{2}$, of which $35 \mathrm{~km}$ is in the territory of Montenegro with a basin area of $413 \mathrm{~km}^{2}(5.12 \%$ of the total area), and in the area of Autonomous Province Kosovo and Metohija it flows in the length of $104 \mathrm{~km}$ area of $3966 \mathrm{~km}^{2}$, or $49.2 \%$ of the total area of the Ibar basin. The Ibar receives a total of 23 tributaries on the territory of Montenegro and the upper part of the Ibar basin is characterized by the highest density of the river network in the Balkans (3492 $\mathrm{m}$ of river flows $\left./ \mathrm{km}^{2}\right)$. The most important tributaries of the Ibar on the territory of Serbia are the rivers Sitnica, Raška, Studenica, Jošanica and Ribnica (Enciklopedija Jugoslavije, 1968; Maletić, M., 1973; Radojičić, B., 2005).

The Ibar is a typical mountain river that has a very branched hydrographic basin into which waters from high mountains flow, and due to the great erosion in the basin and river fall, the river exhibits a torrential character and causes frequent floods in periods of high waters (spring and autumn). The absolute largest water flow on the Ibar at the Leposavić station of $774 \mathrm{~m}^{3} / \mathrm{s}$ was measured on February 19 , 1955, and at the Ribariće station at $302 \mathrm{~m} / \mathrm{s}$ on December 20 . 1955 (Dukić, D., 1977; Ivanović et al., 2011).

The Ibar River basin is divided into upper, middle and lower course. By damming the Ibar with a dam at its upper course, the Gazivoda reservoir was formed with a total length of $22 \mathrm{~km}$ and a volume of 380 million $\mathrm{m}^{3}$ of water. The beginning of the accumulation is in the settlement of Ribariće, and the dam for the accumulation is located in the territory of the settlement of Gazivode (Kosovo and Metohija). After $42 \mathrm{~km}$ flow, the Ibar River emerges from the Ribariće ravine and receives 27 tributaries on its way, most of which are short in course and poor in water. The middle course of the Ibar River starts from the settlement of Gazivode, passes through the area of the town of Kosovska Mitrovica, where the largest Kosovo tributary Sitnica with Lab, $90 \mathrm{~km}$ long with an area of $2861 \mathrm{~km}$, flows into the Ibar. The Ibar River flows towards the north of Serbia's territory, and after the confluence of the Raška River in the town of Raška, the lower course of the Ibar begins in a total length of about $100 \mathrm{~km}$ all the way to the confluence with the West Morava. The width of the Ibar riverbed ranges from $12 \mathrm{~m}$ in the upper course, to $25 \mathrm{~m}$ in the middle and lower course. Due to the congestion of the riverbed with eroded material, the depth is mostly small, except in whirlpools where the depth is about 3 meters (Dukić, D., 1954; Dukić, D., 1977; Development Plan of the Municipality of Zubin Potok, 2006-2009).

\subsubsection{Description of study area}

The water of the Ibar River was sampled (large and small waters) at three locations belonging to the middle and upper course of the Ibar River during 2019 in two periods. The selected locations reflect the condition of the area through which the watercourse flows and are under the direct influence of concentrated and diffuse sources of pollution. The geographical coordinates of the sampling locations were determined using the google map: location L1 settlement Rudnica ( $43^{\circ} 23^{\prime} 38.44^{\prime \prime}$; E $20^{\circ} 67^{\prime} 47.24^{\prime \prime}$ ), location L2 - town of Raška, immediately after the confluence of the Raška River

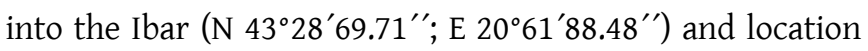

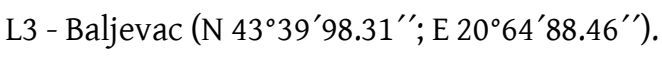

\section{Materials and methods}

Sampling was performed in accordance with the standards for surface water sampling SRPS EN ISO 5667-6: 1997 at all 


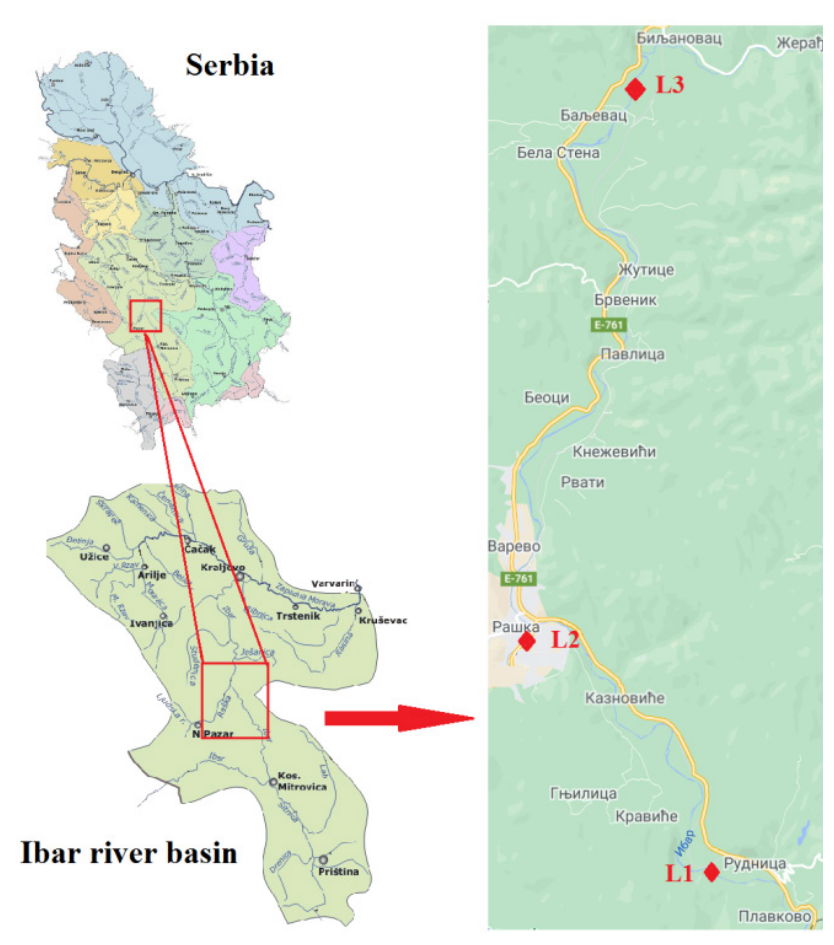

Figure 1. Geographical locations of water sampling the river Ibar. sites. Water samples were taken in 5 liters plastic balloons from a $10 \mathrm{~cm}$ depth from the surface of the water, and for the analysis of heavy metals in plastic bottles of $500 \mathrm{ml}$. Water sampling vessels for heavy metal analysis were purified with $5 \%$ nitric acid HNO3 and then washed with distilled deionized water. Before taking the samples, the dishes were washed three times with water from the sampling location. Water samples for microbiological analysis were taken in sterile glass bottles with a volume of $500 \mathrm{ml}$ according to the standard procedure SRPS EN ISO 19458: 2009. Conservation and transport of water samples were performed according to the guidelines SRPS EN ISO 5667-3: 1997.

Physico-chemical analysis of the general water parameters was performed by standard laboratory-analytical procedures defined in the Manual of Standard Methods for Potable Water Testing (1990) and APHA AWWA WEF standards (2012). The total number of coliform bacteria and fecal coliforms in $100 \mathrm{ml}$ of water was determined in accordance with the standard SRPS EN ISO 9308-1: 2010. The metal concentration in the water samples was determined on an AAS Solar Unicam 969 atomic absorption spectrophotometer manufactured by Pye Unicam, England in accordance with the methods of APHA AWWA WEF (2012) and EPA (1983, 2002). Water samples were acidified with $10 \%$ HNO3 and filtered through a $0.45 \mu \mathrm{m}$ membrane filter (Whatman Merck Millipore Corporation, Darmstadt, Germany), and after the filtration the metals were determined on an AAS apparatus. Prior to heavy metal analysis, the AAS was calibrated according to the manufacturer's instructions.

\subsection{Legislation of the results interpretations}

In the field of water quality, our country's legislation is harmonized with the EU framework directive (WFD, 2000) whose main goal is the sustainable management of water resources and achieving good hydrological, chemical and ecological status of natural waters. According to the bylaw (Official Gazette of the Republic of Serbia No. 74/2011), the Ibar River is classified in Type 2 watercourses into large rivers with a medium sediment dominance for which the boundaries between classes of ecological status are defined. Interpretation of test results and determination of watercourse class was done on the basis of domestic applicable legislation: Regulation on emission limit values of polluting substances in surface and groundwaters and sediment and deadlines for their achievement (Official Gazette of the RS, No. 50/12); Regulation on the parameters of ecological and chemical status of surface water and parameters of the chemical and quantitative status of groundwater (Official Gazette of the RS, No. 74/2011); Regulation on emission limit values of priority and priority hazardous substances which pollute surface waters and deadlines for their achievement (Official Gazette of the RS No. 24/2014).

In addition to the above mentioned regulations, water quality assessment was also performed on the basis of the Regulation on the National List of Environmental Indicators (Official Gazette No. 37/2011) by method of calculating the SWQI index (Serbian Water Quality Index). The main purpose of the SWQI index is to determine the common quality class of surface water, which is not possible on the basis of individual water quality indicators. The SWQI index is determined based on the values of ten physico-chemical and microbiological water quality parameters (water temperature, $\mathrm{pH}$ value, electrical conductivity, oxygen saturation, BOD5, suspended solids, total nitrogen oxides, orthophosphates, ammonium ion and coliform bacteria) which show the overall water quality at the level of one quality class (Veljković, N., 2006; Veljković et al., 2012). The SWQI index has been calculated on the basis of the methodology and calculators available on the website of the Environmental Protection Agency (http://www.sepa.gov.rs). Numerical values and descriptive character of water classes according to the SWQI index number are shown in Table 1.

Table 1. Classification of surface waters using the SWQI

\begin{tabular}{ccccc}
\hline Excellent & Very good & Good & Bad & Very bad \\
\hline $100-90$ & $89-84$ & $83-72$ & $71-39$ & $38-0$ \\
\hline
\end{tabular}




\section{Results and discussion}

\subsection{The identification of the Ibar River pollutants}

The Ibar River is the final recipient for most of the wastewater in its confluence area. The main source of pollution of the Ibar River is untreated communal water from suburbs, garbage dumps, wastewater from mines and mine tailings containing heavy metals, industrial wastewater, as well as agricultural activities in the immediate vicinity of the river. The active drives of RMHK "Trepča" plant (mines, surface mines, flotation plants), flotation and separation tailings of the plant's former drive pose a special pollution problem of the Ibar with high concentrations of heavy metals, which are direct polluters of the Ibar River. Additional pollution of the Ibar is caused by its largest tributary, the Sitnica River, which is the most polluted river in Kosovo and a receiver of wastewater from thermal power plants, municipal water from forty settlements. The river Ljušta, which is the most polluted watercourse with fecal waters in Serbia, and the river Prištevka, which is outside all water quality classes, flow into Sitnica (Ocokoljić et al., 2009). Heavy metals are the most important wastewater component from mines and tailings. For example, $70 \%$ of water is needed for each ton of ore pulp produced. Landfill leachate with high content of heavy metals is released from ore tailings dumps, which reach surface and ground water (Stojanović et al., 1989).

In the settlement of Rudnica, there is a landfill for flotation tailings of the former mine, which constantly pollutes groundwater, soil and the Ibar River. It is estimated that about one million tons of tailings were disposed of in the period from 1972 to 2002 at this landfill. The Raška River, which is very polluted with communal waters and solid waste from the territory of the municipality of Novi Pazar, also flows into the Ibar. According to the report of the daily newspaper Politika from February 9, 2018, the partition mesh dam on the Raška River collected over three tons of plastic waste in just two days. In the settlement of Baljevac, next to the riverbed of the Ibar River, there is a separation and a coal dump, which additionally pollutes the watercourse. Table 2 shows the list of basic pollutants of the Ibar River.

Table 2. List of basic pollutants of the middle and upper course of the Ibar River.

\begin{tabular}{|c|c|c|}
\hline Name of the pollutant & Spill area & Note \\
\hline \multicolumn{3}{|c|}{ Geographical area from the town of Kosovska Mitrovica to the settlement of Rudnica } \\
\hline Municipal wastewater, Zubin Potok & Ibar River & \\
\hline Municipal wastewater, Kosovska Mitrovica & Sitnica River (Ibar’s tributary) & \\
\hline Chemical industry Fafos, Kosovska Mitrovica & Ibar River & \\
\hline Mine wastewater: Jelakce, Koporić & Ibar River & \\
\hline $\begin{array}{l}\text { Mining wastewater of the northern chain of RMHK } \\
\text { "Trepča" plant: Belo Brdo, Crnac, Žuta Prla }\end{array}$ & Ibar River & \\
\hline $\begin{array}{l}\text { Mining wastewater of the middle chain of RMHK } \\
\text { "Trepča", Stari trg, Kosovska Mitrovica }\end{array}$ & Sitnica River (Ibar’s tributary) & \\
\hline Flotation tailings "Žitkovac" Zvečan & Ibar River & Area: 26 ha Quantity: $8.500 .000 \mathrm{t}$ \\
\hline Flotation tailings "Gornje Polje", Zvečan & Ibar River & Area: 55 ha Quantity: $14.500 .000 \mathrm{t}$ \\
\hline Tailings dump "Industrial Park", Kosovska Mitrovica & Sitnica River (Ibar’s tributary) & Area: 35 ha Quantity: $4.200 .000 \mathrm{t}$ \\
\hline Tailings dump "Žarkov potok", Zvečan & Žarkov stream (Ibar`s tributary) & Quantity a: $9.961 .113 \mathrm{t}$ \\
\hline Wood processing industry "Hrast", Leposavić & Ibar River & \\
\hline Glass finishing "Kristal", Leposavić & Ibar River & \\
\hline Metallurgy plant "Ivo Lola Ribar", Lešak & Ibar River & \\
\hline Flotation tailings "Do", Leposavić & Ibar River & Area: 9,22 ha Quant.: $1.200 .000 \mathrm{t}$ \\
\hline Flotation tailings " Bostanište", Leposavić & Ibar River & Area: 9,22 ha Quant: $3.000 .000 \mathrm{t}$ \\
\hline \multicolumn{3}{|c|}{ Geographical area from the settlement of Rudnica to the town of Raška } \\
\hline Communal landfill Rudnica & Ibar River & \\
\hline Flotation tailings " Suva ruda", Rudnica & Ibar River & \\
\hline Dairy "Milkop", Raška & Ibar River & \\
\hline Meat industry "Golija", Raška & Ibar River & \\
\hline Metal industry "Lola progres", Raška & Ibar River & \\
\hline Municipal wastewater, Raška & Ibar River & $2030 \mathrm{m3} /$ day of wastewater \\
\hline Communal landfill Raška & Ibar River & 7.800 tons/year \\
\hline \multicolumn{3}{|c|}{ Geographical area from the town of Raska to the settlement of Baljevac } \\
\hline Communal landfill Baljevac & Ibar River & Volume about: $600 \mathrm{~m}^{3}$ \\
\hline Municipal wastewater, Baljevac & Ibar River & \\
\hline Coal separation and waste coal landfill, Baljevac & Ibar River & 15.000 tons of waste \\
\hline
\end{tabular}

Source: Upravljanje industrijskim otpadom kombinata Trepča (2011); Elezović et al., (2015); Lokalni ekološki akcioni plan opštine Leposavić $2016-2021$. 


\subsection{Water quality of the Ibar River}

The results of physico-chemical and microbiological analyzes of the Ibar River for all three profiles are shown in Table 3. The determined values of the examined parameters of the Ibar River were compared with legal regulations, based on which the water classification was performed at each examined site, which is shown in Table 4.

The values of water temperature and $\mathrm{pH}$ concentration of hydrogen ions were in the expected range in relation to the sampling season at all localities. The $\mathrm{pH}$ value of the water ranged from 8.10 (L3) to 8.38 (L1) in the month of September and corresponded to quality class II all sites. The content of total hardness of water consisting of dissolved salts of calcium and magnesium was relatively stable and ranged from 175 to $216 \mathrm{mg} / \mathrm{l}^{-1} \mathrm{CaCO}_{3}$. Based on the obtained results, it can be concluded that the water of the Ibar River belongs to moderately hard waters at all test sites.

Concentrations of chloride and electrical conductivity as measures of surface water salinity were within the permitted limits for the first water class in all tested samples. The measured values of chloride ranged from $8.5 \mathrm{mg} / \mathrm{l}^{-1}$ (L1 month September) to $14.9 \mathrm{mg} / \mathrm{l}^{-1}$ (L2 month September), and the conductivity values ranged from $391 \mu \mathrm{S} / \mathrm{cm}$ (L2 month September) to $430 \mu \mathrm{S} / \mathrm{cm}$ (L2 month may). The concentration of suspended solids consisting of $70 \%$ solid particles of organic (bacteria, phyto and zooplankton) and $30 \%$ of inorganic origin (silt, soil) in all profiles had values in the MPC limit for the second water class. The highest measured values of 20 (L2) were in the period of high, and the least of 7 (L3) during low water level.

Oxygen regime parameters, dissolved oxygen concentration and percentage of water oxygen saturation had values above $8 \mathrm{mg} / \mathrm{l}^{-1}$ oxygen, i.e. above $90 \%$ saturation, during both testing seasons at all profiles, which corresponds to the first water class. Nutrient concentrations showed the largest oscillations in terms of exceeding the value of the demanding quality of the Ibar water. Based on the measured concentrations of ammonium ions, the water quality did not correspond to quality class II in both sampling periods at none of the profiles, except at the profile of Rudnica (L1) in the spring sampling period where it was $8.10 \mathrm{mgl}^{-1} / 1$. The highest values of this parameter and the most unfavorable quality in both sampling periods were measured on the L2 Raška profile $\left(0.22 \mathrm{mgl}^{-1} / 1\right.$ month September, and month May $0.35 \mathrm{mgl}^{-}$ $1 / 1)$. The situation was similar with the total nitrogen whose values were in the III class of water quality at the localities Rudnica $\left(2.15 \mathrm{mgl}^{-1} / \mathrm{l}\right)$ and Baljevac $\left(2.31 \mathrm{mgl}^{-1} / \mathrm{l}\right)$ in May, and

Table 3. Results of physico-chemical and microbiological analyzes of the Ibar River by localities.

\begin{tabular}{|c|c|c|c|c|c|c|c|c|}
\hline \multirow{2}{*}{ Parameter } & \multirow{2}{*}{ Unit } & \multicolumn{3}{|c|}{ May (locations) } & \multicolumn{3}{|c|}{ September (locations) } & \multirow{2}{*}{$\begin{array}{l}\text { MPC } \\
\text { II class }\end{array}$} \\
\hline & & $\mathrm{L} 1$ & L2 & L3 & $\mathrm{L} 1$ & L2 & L3 & \\
\hline Water temperature & ${ }^{0} \mathrm{C}$ & 15.7 & 15.2 & 16 & 18 & 18.2 & 18.1 & - \\
\hline Suspended matter & $\mathrm{mg} \mathrm{l}^{-1}$ & 19 & 20 & 12 & 9 & 10 & 7 & 25 \\
\hline Dissolved Oxygen (DO) & $\mathrm{mgl}^{-1}$ & 8.7 & 9 & 9.2 & 8.5 & 8.6 & 9.2 & 7 \\
\hline Oxygen saturation of water & $\%$ & 91.84 & 94 & 97.74 & 94.17 & 93.44 & 90.84 & $70-90$ \\
\hline Total hardness $\left(\mathrm{CaCO}_{3}\right)$ & $\mathrm{mg} \mathrm{l}^{-1}$ & 175 & 182 & 178 & 205 & 216 & 207 & - \\
\hline $\mathrm{pH}$ & - & 8.21 & 8.15 & 8.25 & 8.38 & 8.2 & 8.1 & $6.5-8.5$ \\
\hline Electrical conductivity & $\mu \mathrm{S} / \mathrm{cm}$ & 415 & 430 & 395 & 400 & 391 & 407 & 1000 \\
\hline Ammonium ion $\left(\mathrm{NH}_{4}-\mathrm{N}\right)$ & $\mathrm{mg} \mathrm{l}^{-1}$ & 0.10 & 0.22 & 0.15 & 0.18 & 0.35 & 0.28 & 0.10 \\
\hline Nitrite $\left(\mathrm{NO}_{2}-\mathrm{N}\right)$ & $\mathrm{mg} \mathrm{l}^{-1}$ & 0.021 & 0.038 & 0.011 & 0.015 & 0.052 & 0.041 & 0.030 \\
\hline Nitrate $\left(\mathrm{NO}_{3}-\mathrm{N}\right)$ & $\mathrm{mg} \mathrm{l}^{-1}$ & 1.55 & 1.75 & 1.60 & 1.52 & 1.96 & 1.89 & 3.00 \\
\hline Total Nitrogen oxides & $\mathrm{mg} \mathrm{l}^{-1}$ & 1.321 & 1.788 & 1.111 & 1.415 & 2.001 & 1.942 & - \\
\hline Total Nitrogen (TN) & $\mathrm{mgl}^{-1}$ & 2.15 & 2.31 & 1.9 & 1.95 & 2.4 & 2.83 & 2.00 \\
\hline Orthophosphate $\left(\mathrm{PO}_{4}-\mathrm{P}\right)$ & $\mathrm{mgl}^{-1}$ & 0.082 & 0.102 & 0.091 & 0.098 & 0.125 & 0.108 & 0.10 \\
\hline Consumption $\mathrm{KMnO}_{4}$ (COD) & $\mathrm{mgl}^{-1}$ & 5.3 & 5.8 & 5.1 & 7.2 & 12.7 & 11.1 & 10 \\
\hline $\begin{array}{l}\text { Biochemical Oxygen Demand } \\
\left(\mathrm{BOD}_{5}\right)\end{array}$ & $\mathrm{mg} \mathrm{l}^{-1}$ & 2.1 & 3.5 & 3.3 & 3.1 & 4.2 & 3.9 & 4.5 \\
\hline Total organic carbon (TOC) & $\mathrm{mg} \mathrm{l}^{-1}$ & 4.2 & 4.8 & 3.4 & 3.9 & 4.5 & 3.8 & 5 \\
\hline Chlorides $\left(\mathrm{Cl}^{-}\right)$ & $\mathrm{mgl}^{-1}$ & 11.4 & 9.6 & 10.3 & 8.5 & 14.9 & 13.5 & 100 \\
\hline Total Coliform bacteria & $\mathrm{no} / 100 \mathrm{ml}$ & 16500 & 24800 & 21000 & 19000 & 25000 & 20000 & 10000 \\
\hline Fecal coliform & $\mathrm{no} / 100 \mathrm{ml}$ & 8500 & 19800 & 15600 & 9500 & 20000 & 14500 & 1000 \\
\hline Iron (Fe) & $\mathrm{mg} \mathrm{l}^{-1}$ & 1.396 & 1.15 & 1.11 & 0.863 & 0.715 & 0.504 & 0.50 \\
\hline Manganese (Mn) & $\mathrm{mg} \mathrm{l}^{-1}$ & 0.052 & 0.038 & 0.042 & 0.049 & 0.035 & 0.03 & 0.10 \\
\hline Zinc $(Z n)$ & $\mathrm{mg} \mathrm{l}^{-1}$ & 0.093 & 0.08 & 0.052 & 0.071 & 0.062 & 0.038 & 0.20 \\
\hline Copper (Cu) & $\mathrm{mg} \mathrm{l}^{-1}$ & 0.028 & 0.012 & 0.01 & 0.018 & 0.01 & 0.012 & 0.10 \\
\hline Chromium (Cr) & $\mathrm{mgl}^{-1}$ & 0.021 & 0.016 & 0.01 & 0.014 & 0.016 & 0.015 & 0.05 \\
\hline Lead $(\mathrm{Pb})$ & $\mathrm{mg} \mathrm{l}^{-1}$ & 0.038 & 0.033 & 0.025 & 0.027 & 0.021 & 0.017 & 0.014 \\
\hline Nickel (Ni) & $\mathrm{mg} \mathrm{l}^{-1}$ & 0.025 & 0.022 & 0.015 & 0.021 & 0.015 & 0.018 & 0.034 \\
\hline
\end{tabular}


also in September Rudnica $\left(2.40 \mathrm{mgl}^{-1} / \mathrm{l}\right)$ and Baljevac (2.83 $\left.\mathrm{mgl}^{-1} / \mathrm{l}\right)$.

The L2 Raška profile showed a significant deterioration in water quality in terms of nitrite concentrations (May 0.038 $\mathrm{mg} / \mathrm{l}^{-1}$, September $0.052 \mathrm{mg} / \mathrm{l}^{-1}$ ) and orthophosphate (May $0.102 \mathrm{mg} / \mathrm{l}^{-1}$ and September $\left.0.125 \mathrm{mg} / \mathrm{l}^{-1}\right)$ which were the largest in relation to the other two profiles in both sampling periods, which is why the water at this profile is the third class quality. Also, in the period of low water level in September on the profile L3 Baljevac, the water was of III quality

Table 4. Results of physico-chemical and microbiological analyzes of the Ibar River by localities.

\begin{tabular}{|c|c|c|c|c|c|c|}
\hline \multirow[t]{2}{*}{ Parameter } & \multicolumn{3}{|c|}{ May } & \multicolumn{3}{|c|}{ September } \\
\hline & L1 & $\mathrm{L} 2$ & L3 & $\mathrm{L} 1$ & $\mathrm{~L} 2$ & L3 \\
\hline Suspended matter & II & II & II & II & II & II \\
\hline Dissolved Oxygen (D0) & I & I & I & I & I & I \\
\hline $\begin{array}{l}\text { Oxygen saturation of } \\
\text { water }\end{array}$ & 1 & I & I & I & I & I \\
\hline $\mathrm{pH}$ & II & II & II & II & II & II \\
\hline Electrical conductivity & I & I & I & $\mathrm{I}$ & I & I \\
\hline Ammonium ion $\left(\mathrm{NH}_{4}-\mathrm{N}\right)$ & II & $111^{1.2}$ & $\left.11\right|^{1.2}$ & $\left.11\right|^{1.2}$ & $\left.11\right|^{1.2}$ & $\| I^{1.2}$ \\
\hline Nitrite $\left(\mathrm{NO}_{2}-\mathrm{N}\right)$ & II & $111^{1.2}$ & II & II & $111^{1.2}$ & III1.2. \\
\hline Nitrate $\left(\mathrm{NO}_{3}-\mathrm{N}\right)$ & II & II & II & II & II & II \\
\hline Total Nitrogen (TN) & $\mathrm{III} \mathrm{I}^{1}$ & $\mathrm{III}^{1}$ & II & II & $\mathrm{III}^{1}$ & $\mathrm{III}^{1}$ \\
\hline Orthophosphate $\left(\mathrm{PO}_{4}-\mathrm{P}\right)$ & II & $111^{1.2}$ & II & II & $\left.11\right|^{1.2}$ & $1 I^{1.2}$ \\
\hline $\begin{array}{l}\text { Consumption } \mathrm{KMnO}_{4} \\
\text { (COD) }\end{array}$ & II & II & II & II & $\| I^{1}$ & $\| I^{1}$ \\
\hline $\begin{array}{l}\text { Biochemical 0xygen } \\
\text { Demand }\left(\mathrm{BOD}_{5}\right)\end{array}$ & II & II & II & II & II & II \\
\hline $\begin{array}{l}\text { Total organic carbon } \\
\text { (TOC) }\end{array}$ & II & II & II & II & II & II \\
\hline Chlorides ( $\left.\mathrm{Cl}^{-}\right)$ & 1 & 1 & 1 & 1 & 1 & 1 \\
\hline Total Coliform bacteria & $111^{1.2}$ & $111^{1.2}$ & $111^{1.2}$ & $1 \mid I^{1.2}$ & $111^{1.2}$ & $\| I^{1.2}$ \\
\hline Fecal coliform & III ${ }^{1.2}$ & $\mathrm{IV}^{1.2}$ & $\mathrm{IV}^{1.2}$ & $|I|^{1.2}$ & $\mathrm{IV}^{1.2}$ & $I^{1.2}$ \\
\hline Iron (Fe) & $\mathrm{III}^{1}$ & $\mathrm{III}^{1}$ & $\mathrm{III}^{1}$ & $\mathrm{III}^{1}$ & $\mathrm{III}^{1}$ & $\mathrm{III}^{1}$ \\
\hline Manganese (Mn) & II & II & II & II & II & II \\
\hline Zinc (Zn) & II & II & II & II & II & II \\
\hline Copper (Cu) & II & II & II & II & II & II \\
\hline Chromium (Cr) & II & II & II & II & II & II \\
\hline Lead $(\mathrm{Pb})$ & $\| \mathrm{I}^{3}$ & $\| \mathrm{II}^{3}$ & $\| \mathrm{I}^{3}$ & $11 I^{3}$ & $11 I^{3}$ & $\| \mathrm{II}^{3}$ \\
\hline Nickel (Ni) & II & II & II & II & II & II \\
\hline The final class of water & III & III & III & III & III & III \\
\hline $\begin{array}{l}\text { Number of parameters } \\
\text { above MDK }\end{array}$ & 5 & 8 & 5 & 5 & 9 & 9 \\
\hline SWQI & 81 & 74 & 80 & 80 & 72 & 75 \\
\hline $\begin{array}{l}\text { SWQI description water } \\
\text { class }\end{array}$ & Good & Good & Good & Good & Good & $\begin{array}{c}\text { Goo } \\
d\end{array}$ \\
\hline SWQI average value & & & 77 & & & \\
\hline
\end{tabular}

${ }^{1}$ Regulation on emission limit values of polluting substances in surface and groundwaters and and sediment and deadlines for their achievement (Official Gazette of the RS, No. 50/12); ${ }^{2}$ Regulation on the parameters of ecological and chemical status of surface water and parameters of the chemical and quantitative status of groundwater (Official gazette of the RS, No. 74/2011); ${ }^{3}$ Regulation on emission limit values of priority and priority hazardous substances which pollute surface waters and deadlines for their achievement (Official Gazette of the RS No. 24/2014). class in terms of these two parameters (nitrites $0.041 \mathrm{mg} / \mathrm{l}^{-1}$, orthophosphates $0.108 \mathrm{mg} / \mathrm{l}^{-1}$ ).

The measured concentrations of nitrate, total organic carbon (TOC) and biochemical oxygen demand $\left(\mathrm{BOD}_{5}\right)$ were within the limits for class II water quality during both sampling periods at all profiles. The measured values of chemical oxygen demand (COD) in the period of low water level were in the rank of quality class III on profiles L2 Raška and L3 Baljevac. The increased COD values are most likely a consequence of the discharge of untreated communal waters from the settlements of Raška and Baljevac and the diffuse pollution of leachate from communal landfills. It should be noted that COD values through the consumption of potassium permanganate $\mathrm{KMnO}_{4}$ are not a reliable measure of the content of organic matter because they do not include aromatic hydrocarbons, amino acids, petroleum and petroleum products (Dodds, 2002).

The microbiological parameters of the Ibar River were out of quality for both I and II water quality class during both sampling seasons at all control points. According to the number of total coliforms, the quality of the Ibar water corresponded to the III quality class at all profiles, while according to the content of fecal coliforms, the quality of the Ibar River at locations L2 (month May and September 24000 no/100 ml) and L3 (month May $21000 \mathrm{no} / 100 \mathrm{ml}$ ), September $19500 \mathrm{no} / 100 \mathrm{ml}$ ) corresponded to the IV water quality class.

Based on the increased content of nutrients (ammonia ion, nitrites, total nitrogen and orthophosphates) and microbiological indicators of water quality, it can be concluded that there is a constant influx of organic pollution in the Ibar River, which is expressed in low water level and high water temperatures. Most often, increased concentrations of nutrients and coliforms in surface waters are the result of discharges of untreated municipal water, leachate from landfills and discharges of untreated municipal wastewater and diffuse pollution in river banks (Dalmacija et al., 2004).

The concentrations of heavy metals manganese, zinc, copper, chromium and nickel in all tested water samples were within the permitted limits of the MPC for the II water quality class. The relatively low concentrations of heavy metals in the water of the Ibar can be explained by the fact that most mining and industrial plants do not work, which is why the share of wastewater from these two industries has significantly decreased. Increased values of iron and lead during both sampling seasons at all locations have conditioned that the Ibar River has the III water quality class. 
Iron concentrations ranged from $0.504 \mathrm{mg} / \mathrm{l}^{-1}$ to $1.396 \mathrm{mg} / \mathrm{l}$ ${ }^{1}$, and lead concentrations ranged from $0.017 \mathrm{mg} / \mathrm{l}^{-1}$ to 0.038 $\mathrm{mg} / \mathrm{l}^{-1}$. The increased values of iron and lead are primarily a consequence of the inflow of wastewater from mining plants, flotation tailings and industrial wastewater located directly at the banks of the Ibar River (Industrial Waste Management of the Trepča plant, 2011).

According to the Bylaw (Official Gazette of the Republic of Serbia 74/11), the chemical status of surface waters is determined in relation to the limit values of polluting substances, whereby good chemical status has not been achieved in case at least one prescribed limit value is exceeded. Based on the obtained results of laboratory tests of physical and chemical quality of the Ibar River during 2019, it can be stated that no good chemical status was achieved at any of the profiles in both sampling periods.

At the profile of Rudnica (L1), the Ibar River was within the III class of water for the parameters ammonium ion (September), total nitrogen (May), total coliforms, fecal coliforms, iron and nickel (May, September). At the Raška (L3) profile, the Ibar River was within the limit values for the IV class surface waters in relation to the number of fecal coliform bacteria (May, September). Among the parameters that support the ecological status within the limits of the III class during both testing periods were: total colimorphs, ammonium ion, nitrites, total nitrogen, orthophosphates, iron and nickel. Also, the values of chemical oxygen demand were in the rank of quality class III in September. At the profile of Baljevac (L3), the water of the Ibar was within the limits for the IV quality class in relation to the number of fecal coliform bacteria (May, September), while based on the number of total colimorphs it belonged to the III quality class. The values of ammonium ions, iron and nickel were within the limit values for the III class surface waters for both testing periods. Nitrites, total nitrogen, orthophosphates and chemical oxygen demand were in the limits of the III class in September. Increased values of fecal colimorphs and total colimorphs at the profiles of Raška and Baljevac are a consequence of the influence of the polluted Raška River, untreated communal waters and leachate of coastal garbage dumps in the Ibar River.

It can be concluded that the summary ecological status of the water quality of the Ibar River is of moderate ecological status and the III water quality class during both sampling periods at all three measuring locations. According to the bylaw (Official Gazette of the Republic of Serbia No. 50/2012), the surface waters belonging to this class provide conditions for breeding fish from the cyprinidae family and can be used for the following purposes: drinking water supply with prior treatment by coagulation, flocculation, filtration and disinfection, bathing and recreation, irrigation and industrial use.

The calculated average SWQI values for the Ibar River (Table 4) indicate that there were no significant oscillations in terms of index water quality. In both testing periods, numerical values ranged from 72 to 81 points at all three locations, corresponding to the descriptive "good" water indicator. According to the purpose and degree of purity, "good" water is similar to the moderate ecological status and can be used for swimming and recreation of citizens, for water sports, for breeding other species of fish (cyprinidae), or can be used to supply settlements with drinking water by modern purification methods and in the food industry. The SWQI method provides useful information on the water quality class, however the basic limitation is the use of only ten parameters that define primarily organic pollution and not pollution by heavy metals, pesticides and other water toxicants (Leščešen et al. 2014). Based on the data from Table 4, it can be stated that the largest number of exceedances of water parameters in relation to the legal regulations were recorded at the measurement profile of Raška, 8 parameters in May and 9 in September. Then the Baljevac profile follows with 5 parameters in May and 9 in September. At the profile of Rudnica, the value was exceeded by 5 water parameters in both sampling periods. Also, the average values of the SWQI index during both testing periods were the lowest at the measurement profile of Raška where they were 73 points, followed by the profile of Baljevac of 77.5 and the highest average value was at the profile of Rudnica 80.5 points.

In the end, it can be concluded that in its middle and lower course, the Ibar River is a recipient of wastewater from mines, industry, flotation tailings, municipal water and diffuse pollutants (agriculture, illegal landfills) starting from Kosovska Mitrovica and Leposavić to Raška and settlement Baljevac. This is the main reason that many parameters of the water quality of the Ibar River do not meet the limit values of the target I-II class of water quality of the Ibar. The values of the examined water parameters did not show large differences by seasons, on the basis of which it can be concluded that the influence of organic pollutants and heavy metals of iron and lead is constant.

\section{Conclusion}

The Ibar River is the final recipient of wastewater from its tributaries, untreated communal and industrial water, leachate from landfills and polluted water from agricultural land. The main pollutants of the Ibar with heavy metals are the 
active drives of the mining plant "Trepča" and the flotation tailings of the former plants, which are mostly located at the river bank.

Based on the results of the analysis, it can be concluded that neither of the profiles achieved good chemical status in both sampling periods. The water parameters whose concentrations exceeded the approximate limits for I and II class of water quality are: microbiological indicators, ammonium ion, nitrites, total nitrogen, orthophosphates, chemical consumption of oxygen, iron and nickel. Locations with the worst water quality are Raska and Baljevac, where the largest number of pollutants that contribute to organic water pollution is concentrated. The water quality during both testing periods was of relatively similar quality, indicating that the inflow of pollutants into the Ibar River is constant.

The values of the SWQI index ranged from 72 to 81 points, based on which the water of the Ibar River was classified as "good" water at all three locations. According to the Bylaw (the Official Gazette of the Republic of Serbia No. 50/2012), the water of the Ibar River at all three measuring locations during both sampling periods corresponds to a moderate ecological status, i. e. quality class III.

For a more precise definition of the water quality of the Ibar River, it is necessary to do a longer research and more detailed chemical tests that would include biological and hydromorphological analyzes. In order for the water quality of the Ibar River to be satisfactory, it is necessary to form a cadastre of concentrated pollutants according to the amount and degree of pollution, take measures for rehabilitation and remediation of mine tailings, build wastewater treatment plants and rehabilitate uncontrolled municipal landfills.

\section{ORCID iDs}

Saša Obradović @i https://orcid.org/0000-0002-2718-6701

\section{References}

Agencija za zaštitu životne sredine http://www.sepa.gov.rs. APHA, AWWA, WEF (2012). Standard Methods for examinationof water and wastewater. 22nd ed. Washington. Publisher: American Public Health Association, American Water Works Association, Water Environment Federation 2012. 1-1360 pp. ISBN 978-087553-013-0.

Dalmacija, B., Agbaba, J., (2008). Zagađujuće materije u vodenom ekosistemu i remedijacioni procesi, Prirodno-matematički fakultet, Univerzitet $\mathrm{u}$ Novom Sadu, Novi Sad, 1- 386.

Dalmacija, B., Ivančev-Tumbas, I., (2004). Analiza vode - kontrola kvaliteta, tumačenje rezultata, Prirodno-matematički fakultet, Novi Sad. 1-302.

Development Plan of the Municipality of Zubin Potok, 20062009. Zubin Potok, oktober 2006 years, 1-68.

Dnevne novine Politika (2018). https://www.politika.rs/sr/clanak/398068/Srbija/Pregradna-brana-naRaski-polozila-ispit.

Dodds K. Walter, (2002). Freshwater Ecology Concepts and Environmental Applications. Academic Press, An Elsevier Science Imprint San Diego, California, USA. 1-569. ISBN: 0-12-219135-8.

Dukić, D., (1954). Prilog regionalnom poznavanju rečnih režima dolina u Jugoslaviji. Glasnik Srpskog geografskog društva. XXXIV/2, Beograd, 119-128.

Dukić, D., (1977). Vode SR Srbije. Srpsko Geografsko društvo, posebna izdanja, knjiga 44, Beograd, 1-137.

Elezović, N., Takić, Lj., Jovanović, P., (2015). Novi pristup analizi i modelovanju kvaliteta vode. Mining and Metallurgy Engineering Bor, br. 1, 117-140.

Enciklopedija Jugoslavije, (1968). Jugoslavenski leksikografski zavod Mirolav Krleža, Zagreb, Sveska 7, 1-688.

EPA (1983). Methods for chemical analysis of water and wastes. EPA/600/4-79/020. Environmental Protection Agency, Environmental Monitorig and Support Laboratory. United States Cincinnati, Ohio. march 1983, 1430.

EPA (2007). Method 7000B, Revision 2: Flame atomic absorption spectrophotometry. United States Environmental Protection Agency, february 2007.

Ivanović. R., Ivanović, M., Đokić, M., (2011). Hidrografski potencijali ibarskog Kolašina u funkciji razvoja turizma. Glasnik srpskog geografskog društva, Sveska XCI-Br.1, 117-134.

Leščešen, I., Pantelić, M., Dolinaj, D., Lukić T., (2014). Assessment of water quality of the Tisa river (Vojvodina, North Serbia) for ten year period using Serbian Water Quality Index (SWQI). Geographica Pannonica, Volume 18, Issue 4, 102-107.

Lokalni ekološki akcioni plan opštine Leposavić 2016-2021. Leposavić, jun 2016 godine, 1-76. http://www.eleposavic.com/sr/documents/lokalni-ekoloski-akcioniplan-2016-2021.

Maletić, M., (1973). Kosovo nekada i danas. NIP Borba, Ekonomska politika, 1-1024.

Nacrt prostornog plana Republike Srbije od 2021 do 2035 godine. Republika Srbija, Ministarstvo građenivarstva, saobraćaja i infrastrukture, mart 2021, 1-424. 
https://www.mgsi.gov.rs/sites/de-

fault/files/PPRS\%20Nac.pdf.

Ocokoljić, M., Milijašević, D., Milanović, A., (2009). Klasifikacija rečnih voda Srbije po stepenu njihove zagađenosti. Zbornik radova- Geografski fakultet Univerziteta u Beogradu, Sveska LVII, 2009, 7-18.

Pešić, V., Bečelić-Tomin, M., Kerkez Đ., Dalmacija, B., Krčmar, D., (2017). Identifikacija značajnih pritisaka i procena uticaja ispuštanja otpadnih voda na kvalitet vode reke Krivaje. Hemijska industrija, god. 71, br. 5, 2021, 407418.

Priručnik voda za piće - Standardne metode za ispitivanje higijenske ispravnosti (1990). Savezni zavod za zdravstvenu zaštitu. NIP Privredni pregled, Beograd. 1844.

Radojičić, B., (2005). Vode Crne Gore. Filozofski fakultet Nikšić, Institut za geografiju, posebno izdanje, Nikšić, 1-390.

Regulation on emission limit values of polluting substances in surface and groundwaters and and sediment and deadlines for their achievement (official Gazette of the RS, No. 50/12).

Regulation on emission limit values of priority and priority hazardous substances which pollute surface waters and deadlines for their achievement (Official Gazette of the RS No. 24/2014).

Regulation on hazardous substances in water (Official Gazette of the RS No. 31/1982).

Regulation on the National List of Environmental Indicators (Official Gazette No. 37/2011).

Regulation on the parameters of ecological and chemical status of surface water and parameters of the chemical and quantitative status of groundwater (Official gazette of the RS, No. 74/2011).

Simić S., Simić V., (2009). Ekologija kopnenih voda. (Hidrobiologija I). Biološki fakultet Univerziteta u Beogradu. Prirodno-matematički fakultet Univerziteta u Kragujevcu. Zemun. Alta Nova, 1-295. ISBN: 978-86-7078-090-3.

SRPS EN ISO 19458:1997. Kvalitet vode-Uzimanje uzoraka za mikrobiološke analize.

SRPS EN ISO 5667- 6:1997 Kvalitet vode-Uzimanje uzorka Deo 6 Smernice za uzimanje uzimanje uzoraka iz reka i potoka.

SRPS EN ISO 5667-3:2009. Kvalitet vode - Uzimanje uzoraka, deo 3: Smernice za zaštitu uzoraka i rukovanje uzorcima vode.

SRPS EN ISO 9308-1:2010 Kvalitet vode-Otkrivanje i od- ređivanje broja Escherichia coli i koliformnih bakterija-Deo 1: Metoda membranske filtracije.

Stojanović, O., Stojanović, N., Kosanović, Đ., (1989). Štetne i opasne materije, Hemijsko tehnološki priručnik. Rad Beograd 1984, 1-670.

Upravljanje industrijskim otpadom kombinata Trepča (2011). Izveštaj o međunarodnoj konferenciji. Kosovska Mitrovica, 19. i 20. septembra 2011 godine. Organizatori: Kombinat Trepča i UNDP Empowered lives. Resilient nations. 1-33.

Veljković N., (2006). Indikatori održivog razvoja i upravljanje vodnim resursima, Zadužbina Andrejević.1-20. ISBN: 86-7244-517-1.

Veljković, N., Popović, T., Jovičić M., Dopuđa-Glišić, T., (2012). Uticaj klimatskih faktora na kvalitet vodotokova pomoravlja: analiza metodom sSWQIrb, Voda i sanitarna tehnika, broj 5-6. Udruženje za tehnologiju vode i sanitarno inženjerstvo, Beograd, 31-37.

Water Framework Directive (WFD) - European Commission (2000). Directive 2000/60/EC of the European Parliament and of the Council of 23 October 2000, Off. J Eur Union L327:1-73. 